Marquette University

e-Publications@Marquette

$3-1-2011$

\title{
Perspective Paper: Assessing Air Quality as Part of a Physical Therapy Plan of Care
}

Dennis Sobush

Marquette University, dennis.sobush@marquette.edu

Monika Burrescia

Milwaukee Pain Treatment Center

Accepted version. Cardiopulmonary Physical Therapy Journal, Vol. 22, No. 1 (March 2011): 20-24.

Publisher Link (C) 2011 American Physical Therapy Association. Used with permission. 


\title{
Perspective Paper: Assessing Air Quality as Part of a Physical Therapy Plan of Care
}

\author{
Dennis C. Sobush, MA, DPT, CCS; Monika Burrescia, DPT ${ }^{2}$ \\ ${ }^{1}$ Department of Physical Therapy, Marquette University, Milwaukee, WI \\ ${ }^{2}$ The Milwaukee Pain Treatment Center, Milwaukee, WI
}

\begin{abstract}
Purpose: The purposes of this clinical perspective paper are (1) to expand physical therapists' awareness to the topic of air quality as a health priority when providing professional services; and (2) to provide templates for screening the indoor clinical environments and patient profiles to avert respiratory exacerbations, especially in persons with asthma. Summary of Key Points: The location where a physical therapist practices determines the air quality indices to which a person is exposed. Poor indoor air quality can expose a person to even greater compromise of respiration (ie, Sick Building Syndrome) than outdoor air quality secondary to an array of factors like building materials, the ventilation exchange rate of an enclosed space, chemicals used in cleaning, and humidity. Statement of Conclusions: Extrinsic (ie, environmental) and intrinsic (eg, pre-disposition to airway hypersensitivity) factors must be accounted for by physical therapists to safeguard their patients and themselves from experiencing respiratory compromise and/or distress as a result of a treatment session or their place of employment. Recommendations: Efforts to screen indoor environments for potential triggers and patient risk profiles for abnormal airway reactivity should routinely be undertaken. Individualized Action Plans should be prospectively prepared and readied for implementation when warranted.
\end{abstract}

Key Words: asthma, Sick Building Syndrome, indoor air quality, respiratory impairment

\section{INTRODUCTION AND PURPOSE}

Basic to the Oxygen Transport System ${ }^{1-3}$ is the requirement that individuals be able to ventilate with or without mechanical assistance. This sets in motion a chain of events that ultimately permits gas exchange (ie, respiration) to occur for sustaining life and allowing functional performance.

So vital is this process of ventilation that our neurophysiology is hardwired to permit both reflexive (eg, during sleep) and voluntary (eg, during activity) regulation of breathing. ${ }^{4}$

Address correspondence to: Dennis C. Sobush, MA, DPT, CCS, Associate Professor, Department of Physical Therapy, Schroeder Health Complex, 346B, Marquette University, P.O. Box 1881, Milwaukee, WI 53201, Ph: 414-288-3379 (Dennis.Sobush@Marquette.edu).
Anatomically, our entire respiratory tract from the nostrils to the alveoli is lined by respiratory epithelium that has a porous protective shield or layer called the mucosa. This mucous membrane serves as the first line of defense against bacteria, viruses, pollen, animal dander, cigarette smoke, dust, chemicals, automobile exhaust, and any other harmful air pollutants. ${ }^{5}$ The mucosa accomplishes this by producing mucus which traps particles that enter the nasal passages and by cilia that sweep these trapped particles to a point where they can be either cleared from the body by cough or swallowed and destroyed by stomach acids. ${ }^{5}$

When breathing air of desirable quality, the assault and demand placed upon the mucous membranes of the sinuses and respiratory tract is minimal. Descriptors of ideal air quality ${ }^{6}$ include:

- clarity (freedom from pollutants);

- humidity (between $35 \%$ and $55 \%$ );

- temperature (between $65^{\circ}$ and $85^{\circ} \mathrm{F}$ );

- oxygen content $(21 \%$ total volume and $100 \%$ saturation); and

- negative ion content (3,000 to 6,000 nanometer-sized ions per cubic centimeter).

In other words, air that is clean, moist, warm, oxygen rich, and high in negative ions is the most desirable and healthiest air for human beings to breathe. ${ }^{6}$

Certain patients are known to be at increased risk for respiratory compromise secondary to undesirable outdoor and/or indoor air quality exposure. ${ }^{7-9} \mathrm{~A}$ partial listing of such diagnoses and conditions include patients who are very young or elderly, or have:

- Coronary Artery Disease (CAD)

- Chronic Obstructive Pulmonary Disease (COPD)

- immunosuppression by either disease state (eg, Human Immunodeficiency Virus), medication regimen (eg, prolonged corticosteroid use), or medical treatment intervention (eg, chemotherapy and/or radiation therapy) Therefore, the purposes of this clinical perspective paper are: (1) to expand awareness of physical therapists to the topic of air quality as a health priority when providing professional services; and (2) to provide templates for screening the indoor clinical environments and patient profiles to avert respiratory exacerbations, especially in persons with asthma.

\section{Outdoor Air Quality}

Considerable attention is given to outdoor air quality on an international level. The World Health Organization 
(WHO) summarized the risk posed to human health and well-being worldwide as a result of air pollution in a global update report. ${ }^{7}$ Concerns regarding air pollution escalated to the extent that on December 7, 2009, the Climate Change Conference 2009 was convened by the United Nations in Copenhagen, Denmark. ${ }^{10}$ At this conference, 194 negotiating nations participated in a two-week session with the primary purpose of curbing global carbon emissions (eg, man-made greenhouse gases) that threaten the Earth and the quality of air available for people to breathe.

On any given day and in any geographic location within the United States, Air Quality Indices (AQI) can be queried to check on the status of outdoor air. ${ }^{11}$ The AQI will report the degree of air quality impairment to which the mucous membranes of the respiratory tract will be subjected and when a health risk is likely. The AQI is provided by the Environmental Protection Agency (EPA) ${ }^{\mathbf{1 1}}$ for the 5 major air pollutants (ground-level ozone, particulate matter, carbon monoxide, sulfur dioxide, and nitrogen dioxide). On a scale from 0 to 500, the higher the AQI value, the greater the level of air pollution and risk to health. An AQI value less than 100 is generally regarded as satisfactory to protect public health. The AQI is colorcoded according to 6 levels (green is 'Good,' yellow is 'Moderate,' orange is 'Unhealthy for Sensitive Groups,' red is 'Unhealthy,' purple is 'Very Unhealthy,' and maroon is 'Hazardous') of health concern. For example, air quality that is 'Good' (green) has a value from 0 to 50 whereas 'Hazardous"'(maroon) has a value between 301 to 500 meaning an emergency condition for health exists that is likely to affect the entire population.

\section{Indoor Air Quality}

Air quality concerns should not stop with the outdoor air quality alone. Alarmingly, the EPA has reported that indoor air can be as much as 100 times more polluted than outdoor air and yet many Americans may spend $90 \%$ of their time indoors. ${ }^{6,11}$ Consequently, for many people the risks to health may be greater due to exposure to air pollution indoors than outdoors. For this reason, it is important that physical therapists become aware of the warning signs and symptoms of what is referred to in the literature as the "Sick Building Syndrome" or SBS. ${ }^{12-15}$

Operationally defined as a pattern of disease symptoms linked to poor indoor air quality in workplaces, schools, homes, and other buildings, a 'sick building' is one in which $20 \%$ of the occupants experience discomfort that is suspected to be caused by contaminated indoor air. ${ }^{14,15}$ Symptoms and trends likely to be reported by persons affected by SBS include acute discomfort such as: headache; eye, nose, throat irritation; dry cough; dry or itchy skin; dizziness and nausea; difficulty concentrating; fatigue; lethargy; neurotoxic and general health problems; and sensitivity to odors and tastes. ${ }^{12-15}$ The EPA uses SBS to describe situations in which building occupants experience acute health and comfort effects that appear linked to time spent in a building (localized to a particular room, zone, or widespread throughout the building), but no specific illness or cause can be identified..$^{15}$ This is in contrast to 'Building Related IIIness' (BRI) when symptoms of a diagnosable illness can be attributed directly to airborne building contaminants. ${ }^{16} \mathrm{It}$ is estimated that up to $30 \%$ of new or remodeled commercial buildings worldwide and as many as 80 million buildings nationally generate unusually high health and comfort complaints and could be considered 'sick buildings. ${ }^{6}, 14,15$

A wide array of indoor pollutants has proven harmful to the respiratory tract and contribute to SBS and/or BRI. Common among these indoor air pollutants are ${ }^{6,15,16}$ :

- Biological contaminants: bacteria, molds, mildew, viruses, animal dander, dust mites, cockroaches, pollen, and rat or mouse urine and feces.

- Chemicals and chemical solutions: pesticides; carpetcleaning residues and adhesives; formaldehyde used in building construction and insulation materials; aerosol sprays; office equipment chemicals, especially those from photocopiers and computers; products containing methylene chloride as in paint strippers, adhesive removers, and spray paints; benzene as found in stored fuels and paint supplies; and, perchloroethylene from items newly dry-cleaned.

- Combustion products: tobacco smoke; coal- or woodburning fireplaces and stoves; and fuel combustion gases from gas-fired appliances such as ranges, clothes dryers, water heaters, and fireplaces since they produce nitrogen dioxide, carbon monoxide, nitrous oxides, sulfur oxides, hydrocarbons, and formaldehyde.

- Ion depletion or imbalance: excess of positive ions over negative ions.

- Particulates: asbestos.

- Ionizing Radiation: radon.

The Importance of the SBS to Society and to Physical Therapy

The SBS has societal impact on economic and financial well-being. A direct impact may relate to employee sickness or absenteeism, lower productivity and job satisfaction, and higher employee turnover. ${ }^{13}$ Indirect impact may relate more to the costs associated with providing health care for those affected by SBS and conditions such as asthma that are exacerbated by poor indoor air quality. ${ }^{17,18}$

Initiatives have emerged from the American Physical Therapy Association (APTA) related to our profession's role in promoting workplace safety and how "Occupational Health Physical Therapy" favorably impacts an employer's bottom line related to lost work days, productivity, and medical costs. ${ }^{19}$ Estimates have been quoted between $\$ 45$ - $\$ 60$ billion cost to our economy due to work-related Musculoskeletal Disorders (MSDs) among an estimated 1.8 million US workers. However, estimates due to work-related Cardiovascular and Pulmonary Disorders do not receive similar attention. ${ }^{19}$

Guidelines from the APTA for the role of the physical therapist in occupational health include:

"examination and evaluation of individuals with workrelated risk factor(s), impairments, functional limitations, disabilities, or other health-related conditions which prevent individuals from performing their occupational pursuits in 
order to determine a diagnosis, prognosis, and implement intervention as necessary." 20

One of the 24 categories of test and measures related to occupational health in this Guideline specifies "environmental, home, and work (job/school/play) barriers." ${ }^{\prime 20}$ It is important for the physical therapist to consider the degree to which outdoor and/or indoor air quality is unhealthy and identify those individuals, regardless of age, who may be especially sensitive to air pollution. This may be equally as important for the physical therapist's own personal well-being as it would be for her/his patients, particularly if known to have a condition like asthma. ${ }^{21}$

The importance of physical therapists conducting a risk assessment to identify the significant threat that air pollution, both outdoors ${ }^{7-9}$ and indoors, ${ }^{9,11,15}$ has on human health and well-being would be consistent with our professional role in occupational health and be in harmony with our Code of Ethics. ${ }^{22}$ Conducting air-quality risk assessments may prove life-saving for patients undergoing treatment in the physical therapist's clinical practice environment if exposed to potential airway triggers of an acute asthma attack. In addition, educating patients to identify warning signs and symptoms related to 'sick buildings' and poor air-quality at home or at work may avert emergency episodes. As a standard precaution, implementation of the guidelines for facilitating indoor air quality in classrooms for every physical therapy student would simultaneously protect those students who have asthma and those who don't, thereby keeping everyone out of harm's way.

\section{The Importance of Individual Action Plans}

When a patient, clinician, or student is known to have a high risk profile for respiratory compromise due to poor air quality (eg, asthma), it is recommended that an Individual Action Plan (IAP) be created. Modeled after the Asthma Action Plan format that is readily available from the American Lung Association, ${ }^{23}$ it is proposed that an IAP should contain:

- general information specific to the person with respiratory compromise (eg, an emergency contact person in addition to his or her physician, including phone numbers);

- the person's diagnosis or condition contributing to respiratory compromise (eg, immuno-suppression) along with severity;

- exposure history to poor outdoor (eg, urban setting) and indoor (eg, second-hand smoke) air quality;

- documentation of the 'triggers' to a person experiencing airway hyper-reactivity (eg, exercise induced bronchospasm);

- a listing of any control (eg, inhaled corticosteroid) and quick relief (eg, beta-2 agonist) medications, doses, and when they should be taken;

- a personal best peak flow rate and corresponding values and symptoms which designate that the person is 'Doing Well' (green zone = greater than $80 \%$ of the personal best), 'Getting Worse' (yellow zone = between $50-80 \%$ of the personal best), and 'Medical Alert' (red zone $=$ less than $50 \%$ of the personal best);

- step-by-step actions for the person to take if in the yellow or red zones; plans for ambulance/emergency transport (eg, 911);

- a designated place where the IAP(s) can be kept for expeditious implementation.

\section{Occupational Physical Therapy Recommendations for Safe Exposure to Outdoor and Indoor Air Quality}

Several recommendations are offered to the physical therapist to protect patients, students, coworkers, and family members from threats by poor air quality:

- Check the outdoor air quality status for a given geographic location on a given day. This can be accomplished by logging onto the Web site http:// www.airnow.gov/index.cfm?action $=$ aqibasics.aqi ${ }^{8}$ and/ or http://www.stateoftheair.org/; ${ }^{24}$

- Become familiar with the World Health Organization (WHO) air quality guidelines for exposure to reduce the health effects of pollution for the patients to whom you provide professional services. Table 1 provides values and exposure times that should not be exceeded; ${ }^{7}$

- Conduct a routine risk assessment for airway hypersensitivity (past/recent/current history of asthma) and pre-existing pulmonary conditions (ie, obstructive and/ or restrictive ventilatory impairment), especially for the very young or the elderly;

- Create IAPs for patients receiving medical treatment for respiratory compromise and have them readily available for implementation in case of emergency;

- Document whether SBS or BRI signs and/or symptoms were identified and/or experienced as a result of the physical therapy treatment visit;

- Identify if 'sick building' factors exist and implement source control strategies to eliminate individual sources of indoor air pollution or reduce their emissions. Table 2 has been prepared to serve as a guide for multiple settings.

Table 1. World Health Organization (WHO) Air Quality Guidelines (AQG) for Exposure to Reduce Adverse Health Effects of Pollution ${ }^{7}$

\begin{tabular}{|c|c|c|}
\hline Pollutant & $\begin{array}{c}\text { Exposure Averaging } \\
\text { Time* }\end{array}$ & AQG Value \\
\hline \multirow{2}{*}{$\begin{array}{l}\text { Particulate Matter } \\
\left(\mathrm{PM}_{2.5}\right)\end{array}$} & 1 year & $10 \mu \mathrm{g} / \mathrm{m}^{3}$ \\
\hline & 24 hours & $25 \mu \mathrm{g} / \mathrm{m}^{3}$ \\
\hline \multirow{2}{*}{$\begin{array}{l}\text { Particulate Matter } \\
\left(\mathrm{PM}_{10}\right)\end{array}$} & 1 year & $20 \mu \mathrm{g} / \mathrm{m}^{3}$ \\
\hline & 24 hours & $50 \mu \mathrm{g} / \mathrm{m}^{3}$ \\
\hline Ozone, $\mathrm{O}_{3}$ & $\begin{array}{l}8 \text { hour, daily } \\
\text { maximum }\end{array}$ & $100 \mu \mathrm{g} / \mathrm{m}^{3}$ \\
\hline \multirow{2}{*}{$\begin{array}{l}\text { Nitrogen Dioxide, } \\
\mathrm{NO}_{2}\end{array}$} & 1 year & $40 \mu \mathrm{g} / \mathrm{m}^{3}$ \\
\hline & 1 hour & $200 \mu \mathrm{g} / \mathrm{m}^{3}$ \\
\hline \multirow[t]{2}{*}{ Sulfur Dioxide, $\mathrm{SO}_{2}$} & 24 hours & $20 \mu \mathrm{g} / \mathrm{m}^{3}$ \\
\hline & 10 minutes & $500 \mu \mathrm{g} / \mathrm{m}^{3}$ \\
\hline
\end{tabular}


Table 2. Action Plan for Improving Indoor Air Quality

\begin{tabular}{|c|c|c|c|}
\hline $\begin{array}{l}\text { Factors to be Monitored and/or } \\
\text { Controlled }\end{array}$ & Physical Therapy Clinic or Classroom & Patient's Home or Place of Employment & Your Personal Residence \\
\hline \multicolumn{4}{|l|}{ Identify and eliminate airway triggers } \\
\hline Dust and vacuum room(s) regularly & $\begin{array}{l}\text { Not while patients or students are } \\
\text { present }\end{array}$ & $\begin{array}{l}\text { Not while the patient or employees are } \\
\text { in the same room }\end{array}$ & $\begin{array}{l}\text { Consider wearing a protective } \\
\text { ventilation mask for whomever } \\
\text { performs this task }\end{array}$ \\
\hline $\begin{array}{l}\text { Clean up mold and repair water leaks } \\
\text { and avoidance of standing water }\end{array}$ & $\begin{array}{l}\text { Especially in hydrotherapy treatment } \\
\text { areas and in classrooms when below } \\
\text { ground- level; dry water-damaged areas } \\
\text { within } 24-48 \text { hours }\end{array}$ & $\begin{array}{l}\text { Especially in patient's bathroom(s), } \\
\text { employee restrooms, and rooms that are } \\
\text { below ground-level; dry water-damaged } \\
\text { areas within } 24-48 \text { hours }\end{array}$ & $\begin{array}{l}\text { Especially in your bathroom(s) and } \\
\text { rooms that are below ground-level; } \\
\text { dry water-damaged areas within 24-48 } \\
\text { hours }\end{array}$ \\
\hline Control pests & $\begin{array}{l}\text { Don't leave food out and dispose of } \\
\text { trash promptly and properly; follow } \\
\text { manufacturer's safety advice if pesticide } \\
\text { use is necessary; close up/seal cracks } \\
\text { and crevices in building foundation and } \\
\text { in roofs or attics }\end{array}$ & $\begin{array}{l}\text { Don't leave food out and dispose of } \\
\text { trash promptly and properly; follow } \\
\text { manufacturer's safety advice if pesticide } \\
\text { use is necessary; close up/seal cracks } \\
\text { and crevices in building foundation, } \\
\text { garages, and in roofs or attics }\end{array}$ & $\begin{array}{l}\text { Don't leave food out and dispose of } \\
\text { trash promptly and properly; follow } \\
\text { manufacturer's safety advice if pesticide } \\
\text { use is necessary; close up/seal cracks } \\
\text { and crevices in building foundation, } \\
\text { garages, and in roofs or attics }\end{array}$ \\
\hline Avoid sources of secondhand smoke & $\begin{array}{l}\text { Public buildings should be designated } \\
\text { as smoke-free environments such that } \\
\text { secondhand smoke is unlikely to be a } \\
\text { problem }\end{array}$ & $\begin{array}{l}\text { Smoking of tobacco products must not } \\
\text { be permitted inside the home or motor } \\
\text { vehicles; Public buildings should be } \\
\text { designated as smoke-free environments }\end{array}$ & $\begin{array}{l}\text { Smoking of tobacco products must not } \\
\text { be permitted inside your home or motor } \\
\text { vehicles you operate }\end{array}$ \\
\hline $\begin{array}{l}\text { Use allergen-proof soft furniture } \\
\text { and coverlets and keep them clean }\end{array}$ & $\begin{array}{l}\text { Select cushions, mattresses, pillows, and } \\
\text { positioning devices that are allergen- } \\
\text { proof; wash pillow cases, linens, and } \\
\text { blankets in hot water at least weekly or } \\
\text { more often as needed }\end{array}$ & $\begin{array}{l}\text { Select cushions, pillows, mattresses, and } \\
\text { positioning devices that are allergen- } \\
\text { proof; wash pillow cases, linens, and } \\
\text { blankets in hot water at least weekly or } \\
\text { more often as needed; keep pets out of } \\
\text { the bedroom and off soft furniture }\end{array}$ & $\begin{array}{l}\text { Select cushions, mattresses, pillows, and } \\
\text { positioning devices that are allergen- } \\
\text { proof; wash pillow cases, linens, and } \\
\text { blankets in hot water at least weekly or } \\
\text { more often as needed; keep pets out of the } \\
\text { bedroom and off soft furniture }\end{array}$ \\
\hline \multicolumn{4}{|c|}{ Exercise caution in the use of volatile organic compound (VOC) products } \\
\hline $\begin{array}{l}\text { Read and follow all directions and } \\
\text { warnings on VOC products (e.g. paints } \\
\text { and lacquers, paint strippers, varnishes, } \\
\text { cleaning supplies, air fresheners, } \\
\text { pesticides, and building materials) }\end{array}$ & $\begin{array}{l}\text { Minimize the use of VOCs (ie, chemicals } \\
\text { that evaporate at room temperature) when } \\
\text { patients or students are present; allow for } \\
\text { adequate ventilation when VOCs are } \\
\text { likely to be released into the environment; } \\
\text { educate the person using VOCs how to } \\
\text { minimize exposure to toxic fumes }\end{array}$ & $\begin{array}{l}\text { Minimize the use of VOCs (ie, chemicals } \\
\text { that evaporate at room temperature) when } \\
\text { the patient or employees are present; } \\
\text { allow for adequate ventilation when } \\
\text { VOCs are likely to be released into the } \\
\text { home or workplace; educate the person } \\
\text { using VOCs how to minimize exposure to } \\
\text { toxic fumes }\end{array}$ & $\begin{array}{l}\text { Minimize the use of VOCs (ie, chemicals } \\
\text { that evaporate at room temperature) when } \\
\text { family members or guests are present; } \\
\text { allow for adequate ventilation when } \\
\text { VOCs are likely to be released into the } \\
\text { home; educate the person using VOCs } \\
\text { how to minimize exposure to toxic fumes }\end{array}$ \\
\hline Store all VOCs properly & $\begin{array}{l}\text { Store VOCs in well- ventilated or vented } \\
\text { areas; don't store VOCs in areas in close } \\
\text { proximity to patients or students }\end{array}$ & $\begin{array}{l}\text { Store VOCs in well- ventilated or vented } \\
\text { areas; don't store VOCs in areas in close } \\
\text { proximity to the patients or employees; } \\
\text { keep all VOCs away from children }\end{array}$ & $\begin{array}{l}\text { Store VOCs in well- ventilated or vented } \\
\text { areas; keep all VOCs away from children }\end{array}$ \\
\hline \multicolumn{4}{|c|}{ Screen and monitor for the safe and proper use of all fuel-burning appliances (i.e. furnaces, gas stoves, fireplaces, chimneys, space-heaters, etc.) } \\
\hline $\begin{array}{l}\text { Confirm that these appliances were } \\
\text { properly installed and adjusted }\end{array}$ & $\begin{array}{l}\text { Whenever possible, such appliances } \\
\text { should be vented to the outside; carbon } \\
\text { monoxide }(\mathrm{MO}) \text { detectors should be } \\
\text { available and operational }\end{array}$ & $\begin{array}{l}\text { Whenever possible, such appliances } \\
\text { should be vented to the outside; carbon } \\
\text { monoxide (MO) detectors should be } \\
\text { available and operational }\end{array}$ & $\begin{array}{l}\text { Whenever possible, such appliances } \\
\text { should be vented to the outside; carbon } \\
\text { monoxide }(\mathrm{MO}) \text { detectors should be } \\
\text { available and operational }\end{array}$ \\
\hline $\begin{array}{l}\text { Confirm that these appliances are being } \\
\text { used and maintained properly }\end{array}$ & $\begin{array}{l}\text { Identify that there is an informed and/or } \\
\text { qualified person or person(s) who is/ are } \\
\text { responsible for the proper upkeep and } \\
\text { operation of these appliances according to } \\
\text { the manufacturer's instructions }\end{array}$ & $\begin{array}{l}\text { Identify that there is an informed and/ } \\
\text { or qualified person or person(s) who is/ } \\
\text { are responsible for the proper upkeep and } \\
\text { operation of these appliances according } \\
\text { to the manufacturer's instructions }\end{array}$ & $\begin{array}{l}\text { Identify that you are properly informed } \\
\text { and capable of assuming responsibility } \\
\text { for the proper upkeep and operation } \\
\text { of these appliances according to the } \\
\text { manufacturer's instructions }\end{array}$ \\
\hline \multicolumn{4}{|c|}{ Establish the safety of radon gas levels for the building being occupied } \\
\hline $\begin{array}{l}\text { Verify the radon gas levels that exist for } \\
\text { the building }\end{array}$ & $\begin{array}{l}\text { Especially important when the patient } \\
\text { treatment area(s) or classrooms are below } \\
\text { ground-level }\end{array}$ & $\begin{array}{l}\text { Especially important when patient } \\
\text { treatment area(s) or classrooms are below } \\
\text { ground-level }\end{array}$ & $\begin{array}{l}\text { Especially important when the rooms are } \\
\text { below ground-level }\end{array}$ \\
\hline
\end{tabular}




\section{SUMMARY AND CONCLUSION}

The location where a physical therapist practices determines air quality indexes to which a person is exposed. Poor indoor air quality can expose a person to even greater compromise of respiration (ie, Sick Building Syndrome) than outdoor air quality due to an array of factors like building materials, the ventilation exchange rate of an enclosed space, chemicals used in cleaning, and humidity.

Extrinsic (ie, environmental) and intrinsic (eg, predisposition to airway hypersensitivity) factors must be accounted for by physical therapists to safeguard their patients and themselves from experiencing respiratory compromise and/ or distress as a result of a treatment session, their home, or their place of employment.

Efforts to screen indoor environments for potential triggers and patient risk profiles for abnormal airway reactivity should routinely be undertaken. Individualized Action Plans should be prospectively prepared and readied for implementation when warranted.

\section{REFERENCES}

1. Dean E. Preferred practice patterns in cardiopulmonary physical therapy: A guide to physiologic measures. Cardiopulm Phys Ther J. 1999;10(4):124-134.

2. American Physical Therapy Association. Guide to physical therapist practice: $2^{\text {nd }}$ ed. Phys Ther. 2001;81(1):1-746.

3. Frownfelter D, Dean E. Cardiovascular and Pulmonary Physical Therapy: Evidence and Practice. $4^{\text {th }}$ ed. St. Louis, MO: Mosby Elsevier; 2006.

4. Guyton AC, Hall JE. Chapter 41 Regulation of Respiration. In: Textbook of Medical Physiology. $11^{\text {th }}$ ed. Philadelphia, PA: Elsevier Saunders; 2006.

5. Guyton AC, Hall JE. Chapter 37 Pulmonary Ventilation. As found in Textbook of Medical Physiology. $11^{\text {th }}$ ed. Philadelphia, PA: Elsevier Saunders; 2006.

6. Ivker RS. Sinus Survival: The Holistic Medical Treatment for Sinusitis, Allergies, and Colds. $4^{\text {th }}$ ed. New York, NY: Penguin Putnam Inc.; 2000.

7. World Health Organization: WHO Air Quality Guidelines for Particulate Matter, Ozone, Nitrogen Dioxide and Sulfur Dioxide: Global Update 2005 Summary of Risk Assessment. Geneva, Switzerland; 2006. http://whqlibdoc.who.int/hq/2006/WHO_SDE_ PHE_OEH_06.02_eng.pdf. Accessed September 20, 2010.

8. AIRNow. United States Government Website for Air Quality Information. http://www.airnow.gov/index. cfm?action=aqibasics.aqi. Accessed September 20, 2010.

9. United States Environmental Protection Agency: Care for Your Air: A Guide to Indoor Air Quality (EPA 402/F08/008). September, 2008. http://www.epa.gov/iaq. Accessed September 20, 2010.

10. United Nations Climate Control Conference 2009. Copenhagen, Denmark; December 7, 2009. http:// www.denmark.dk/en/menu/Climate-Energy/COP15Copenhagen-2009/ Accessed September 20, 2010.
11. United States Environmental Protection Agency/ Office of Air and Radiation: The Inside Story: A Guide to Indoor Air Quality. http://www.epa.gov/iaq/pubs/ insidest.html. Accessed September 20, 2010.

12. Cooley JD, Wing CW, Jumper CA, Straus DC. Correlation between the prevalence of certain fungi and sick building syndrome. Occup Environ Med. 1998;55:579-584.

13. Thorn A. Case study of a sick building. Eur J Public Health. 2000;10(2):133-136.

14. Niven R, Fletcher AM, Pickering CA, et al. Building sickness syndrome in healthy and unhealthy buildings: an epidemiological and environmental assessment with cluster analysis. Occup Environ Med. 2000;57:627634.

15. United States Environmental Protection Agency/Office of Air and Radiation: Indoor Air Facts No. 4 (revised) Sick Building Syndrome. http://www.epa.gov/iaq/pubs/ sbs.html. Accessed September 20, 2010.

16. Fletcher LA, Gaunt LF, Beggs CB, et al. Bactericidal action of positive and negative ions in air. $B M C$ Microbiology. 2007;7(32): 1-9.

17. Eggleston PA. The environment and asthma in US inner cities. Chest. 2007;132:782S-788S.

18. Pope CA, Burnett RT, Thun MJ, et al. Lung cancer, cardiopulmonary mortality, and long-term exposure to fine particulate air pollution. I Am Med Assoc. 2002;287(9):1132-1141.

19. American Physical Therapy Association: Occupational Health Physical Therapy. Emerging PT Practice: Number 3. 2000.

20. American Physical Therapy Association: Guidelines: Occupational Health Physical Therapy: Legal and Risk Management Issues. BOD G02-02-16-02. http:// www.apta.org/AM/Template.cfm?Section=Policies and_Bylaws\&TEMPLATE=/C. Accessed September 20, 2010.

21. Kavuru MS. Diagnosis and Management of Asthma. $3^{\text {rd }}$ ed. American Lung Association; 2006.

22. Swisher LL, Hiller P, American Physical Therapy Association Task Force to Revise the Code of Ethics: The revised APTA code of ethics for the physical therapist and standards of ethical conduct for the physical therapist assistant: theory, purpose, process, and significance. Phys Ther. 2010;90(5):803-824.

23. American Lung Association: Breathe Well, Live Well: An Asthma Management Program for Adults. Krames and American Lung Association. 2007. http://www. lungusa.org/assets/documents/program-pdfs/asthmaaction-plan.PDF Accessed September 20, 2010.

24. American Lung Association. http://www.stateoftheair. org/ Accessed September 20, 2010. 